Journal of Education and Vocational Research

Vol. 2, No. 1, pp. 10-17, July 2011 (ISSN 2221-2590)

\title{
A Study Examining the Effect of Oil Exports on Agricultural Value added in Iran
}

\author{
${ }^{1}$ Safdari Mehdi, ${ }^{2}$ Motiee Reza* \\ 1Department of Economics, University of Qom, Iran \\ ${ }^{2}$ Department of Economics, Babol Branch, Islamic Azad University, Babol, Iran \\ *rm.search2011@gmail.com
}

\begin{abstract}
The slower economic growth in some countries with high natural resources shows an unsolved dilemma in economics when we compare the economic growth of such countries with some other countries that are poor in natural resources but surprisingly have a higher economic growth. The purpose of this study is to determine the relationship between oil exports and agricultural value added in Iran. The theoretical framework was designed based on this assumption that the total production in the economy is divided into two sections: production for inside and production for exports. The data were collected from 1961 to 2006 and were analyzed using Auto Regressive Distributed Lag (ARDL) model. The result of the analyses showed that there was significant relationship between oil export and agricultural value added. Error correction coefficient is negative and small and is equal to -0.31 and it shows that if there is any shock or imbalance in total production, the system will be back to stability after a 3-year period. Together the independent variables explained $83 \%$ of the variance in the dependent variables. The remaining $17 \%$ was due to unidentified variables. In relation to that, we can conclude that explanatory power is high for the equation. It showed that one percent change in oil export rate lead to decrease $13 \%$ in agricultural value added. Therefore oil exports have negative effects on agricultural value added and is regarded as an important factor in Iran's agricultural value added.
\end{abstract}

Key Words: Structural Break, ARDL method, Oil Exports, Agricultural Value Added

\section{Introduction}

Retard of economic growth of countries that are owners of natural sources (such as oil exports) and better operation of macroeconomic in poor countries from natural sources point of view are considered as a non matter of course phenomenon in economic developing literature. In the 20th century, Switzerland and Japan, poor from natural resources point of view, in comparison with Russia, beneficiary from natural sources, had better economic operation. Cynicism about economical developing that is based on natural resources results from foresight about demand and downswing and frequency of worldly prices of natural sources. Studies show that retard of economical growth in countries that are owner of natural resources, even after controlling worldly prices of these sources is an experimental reality.

From the historical point of view, during the development process, the share of agricultural sector will decrease in production and workforce. Because of this, some of the experts believe that agriculture is a secondary factor in the process of economic development. Thus, the decrease in its products and workforce could be a consequence of discriminatory national policies and the international trade mechanisms. The agricultural sector, as the stimulator of economical development, especially in developing and poor countries has an important role in improving the food security, decreasing the price of food products, increasing the employment rate and income, making important economical relations in production chain and causing positive effects on environment. One of the goals of the third FYDP ${ }^{1}$ development program (2000-2003) was expanding the non-oil exports, and as agricultural products are on of the main sources of non-oil exports, Importance and influence of the export of these products on the economical growth in agricultural sector and, as a result, in the whole country gets obvious. So, extending the scientific studies on this matter is necessary. In this research we study the effect of oil exports on agricultural value added division in Iran as an oil exporter during 1960 to 2007.

\footnotetext{
${ }^{1}$ Iran's FYDP was initiated since the end of Iran-Iraq war in 1988. High rates of economic growth for a decade is a strategic approach as well as an outstanding issue in the fourth five-year development plan of Iran (March 2005-2010).
} 
Dutch Disease Analysis: In 1959, after the discovery of natural gas resources and fast increase in its exports, huge income, exports income, as foreign exchange, introduced into Netherlands economy and total demand increased. In addition, a meaningful difference appeared between elements price and price index in different sectors. This situation weakened the tradable sector and strengthened the untradeable sector. So, the foreign exchange income caused the deindustrialization phenomenon in Netherlands. The root of this phenomenon was the natural gas exports income. ${ }^{1}$ Dutch Disease theory could be summarized in two subjects: spending effect and resource effect. Of an economy encounters an unexpected increase in exports income, this could lead to general increase in incomes and then to an increase in domestic demand. The main reaction of an economy to such a momentum is an increase in working population demand and then an increase in workforce wages. Ultimately, the effect of such a momentum would lead to a decline in money value and the true rate of foreign exchange; which decreases the country's ability to compete in international scenes. It's worth mentioning that Dutch Disease theory is only applicable when swings are temporary and transient. If they're permanent, true rate of foreign exchange can react to this swings which could accepted as an ordinary and regular reaction in economy.

Agricultural Sector: The composition of the Iranian GDP after the revolution has changed significantly. The agricultural growth rates are presented in Fig.1. During the pre-revolution period (1960-1978), the agricultural sector had an average growth rate of approximately 4.4 percent per annum. During the ten years following the revolution, the agricultural sector grew by approximately 4.3 percent annually. This shows that although the Iranian economy as a whole was affected very negatively by the war, the agricultural sector was less seriously affected than other sectors of the economy. Following the cease fire, the agricultural sector had an annual growth rate of 6.4 percent over the length of the first Five-year Economic Development Plan (FYDP). During the second FYDP (1995-1999), however, a serious and dramatic reduction in the amount of rainfall caused the average growth rate in the agricultural sector to fall to 2.2 percent, far below its target of 4.3 percent growth and During the 3th FYDP (2000-2004), the agricultural sector had an annual growth rate of 4.4 percent (Central bank of Iran). The agricultural sector enjoyed an average annual growth rate of 4.3 percent during the whole period after the revolution, reaching a peak of 11 percent in 1990. The lowest rate of -7.3 percent have been occurred in 1999 due to a drought (See Fig. 1).

Figure 1: Annual Growth Rate of the Agriculture Sector at Constant 1997 Price (1960-2007)

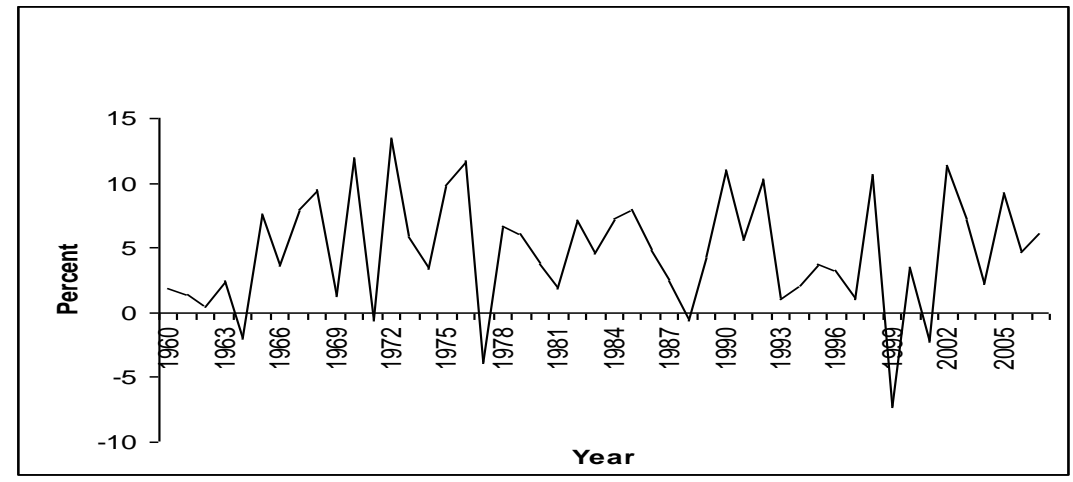

Source of the data: Central Bank of Iran (2007b)

Composition of Non-Oil Exports by Sector: Iran's non-oil exports fall into four major categories, namely: agricultural products, mining and mineral products, industrial products and carpets and handicrafts. However, the nature of non-oil goods which have been exported has been heavily weighted in favor of traditional and agricultural products. Table 1 shows that In 2007, Iran exported \$US 15.3 billion non-oil goods of which 22.7 percent consisted of traditional and agricultural products, 75.8 percent industrial and petrochemical products and about 1.5 percent mineral materials.

\footnotetext{
${ }^{1}$ The theoretical framework of this analysis is based on a dependent-tiny economy which is facing unexpected and temporary swings in the income of raw material exports (Salter, 1959). Based on this theory, when economy is in such situation, instability in oil income leads to a less ability to compete in tradable sector of traditional markets. This economic phenomenon is called Dutch Disease (Gorden \& Neary, 1982; Neary \& Van Wigenbergen, 1986).
} 
Figure 2: Non Oil Export Groups of Goods during 2004-2005

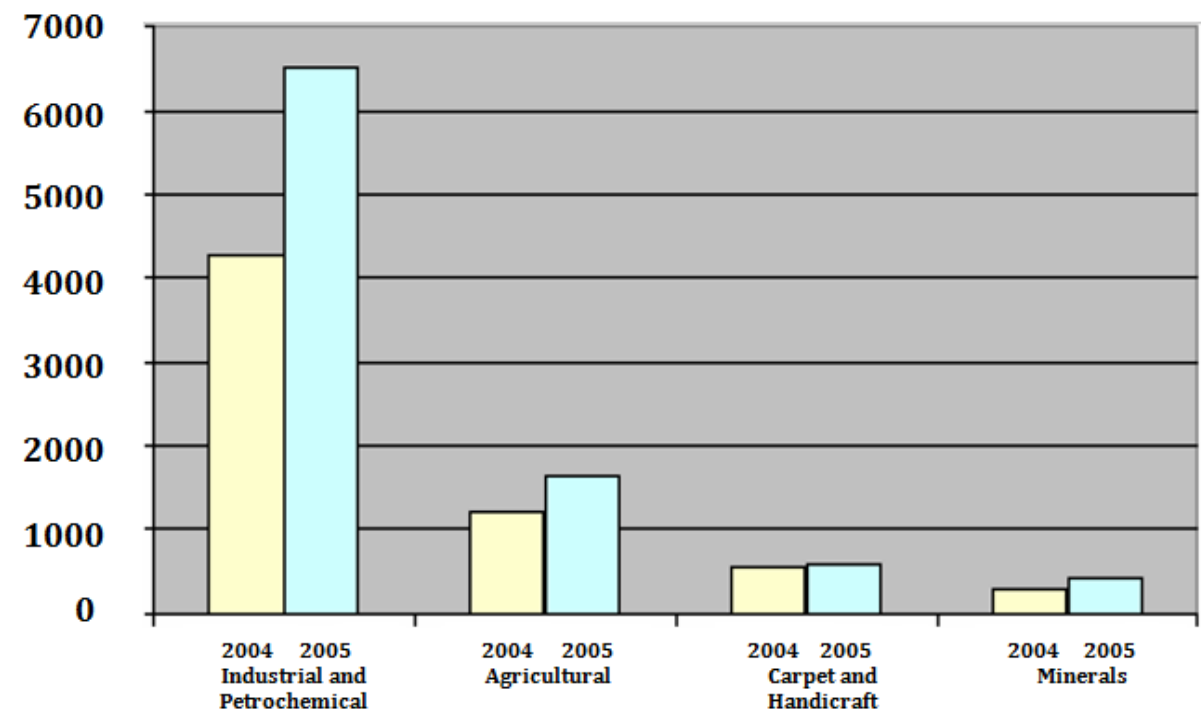

Table 1: Share of Different Groups in the total Value of Non-Oil Exports

\begin{tabular}{lcccc}
\hline Non-oil exports & \multicolumn{2}{c}{ Value (\$US Million) } & \multicolumn{2}{c}{ Share (\%) } \\
& $\mathbf{2 0 0 6}$ & $\mathbf{2 0 0 7}$ & $\mathbf{2 0 0 6}$ & $\mathbf{2 0 0 7}$ \\
\hline Traditional and & & & & \\
Agricultural products & 3012 & 3482 & 23.2 & 22.7 \\
Industrial Products & 9664 & 11603 & 74.4 & 75.8 \\
Metallic mineral products & 321 & 227 & 2.4 & 1.5 \\
Total & 12997 & 15312 & 100 & 100 \\
\hline
\end{tabular}

Source: Central Bank of Iran

Official data show that while in 1989 the export of industrial products stood at 11.7 percent of total non-oil exports, this share had increased to 32.1 percent by the end of 2th FYDP in 1999 and had increased to 27.6 percent by the end of 3th FYDP in 2004. In contrast, the share of agricultural products and traditional goods (such as carpets, pistachio nuts, caviar, and saffron) over total non-oil exports decreased very significantly from 68 percent in 1979 to around 22.7 percent in 2007 (EPCI ${ }^{1}, 2001,2008$; CBI, 2001b,2008b). The top ten non-oil export items in this year were: hand-woven carpets, chemical products, pistachios and other nuts, ironware and steel, other industrial commodities, textiles, copperware, animal hides, as well as benzene and its derivatives (ICCIM², 2000).

In Iran such as other countries, growth and achieve the high rate is one of the goals of government. Hence review factors impact on growth including exports can be the way for economic policy maker's framework intended purpose. The purpose in this study is the survey effect of oil exports on agricultural value added in Iran and we want to estimate model the using Auto Regressive Distributed Lag (ARDL) and time-series data of 1961-2006 published by central bank of Iran and statistical center of Iran and then to test hypotheses related to research based on statistical inference and also we want to answer this question: can be oil export a cause for agricultural value added?

\section{Literature Review}

Feder (1982) studied the relationship between exports and economic growth by separating the total production into two sectors and he showed that productivity is higher in exports sectors than non-exports

\footnotetext{
${ }^{1}$ Export Promotion Center of Iran

${ }^{2}$ Iran chamber of commerce industries \& mines
} 
sectors. Sheehey (1990) reviewed the relation between exports and economic growth by criticizing in the previous researches. His main criticism is that the exports are a part of Gross Domestic Product (GDP) and so there is a build in relationship between these two. So if we use Spearman test there wouldn't always be a strong relationship between these parameters. This criticism is also true about production-function-type regressions. Mellor (1995) showed that growth of agriculture in countries that have natural resources is more retard than growth consequent of industry in countries without natural resources. Fosu (1996) experimental work is another works about the effect of exports on economic growth. In his research, he studies the role of raw material exports on GDP growth and GDP growth minus exports, effect of raw material exports on GDP growth. He examines the theory that says: growth in raw material exports can't fill the gap between North and South countries. Martin (1997) and Doppelhofer et al. (2000) considered natural resources as most important variations is empirical studies about economical growth. Esfahani (1991) shown that extrovert policies are key to long-term national development. He argued about the relationship between exports and economic growth in less developed countries. His empirical shows that difference between the lack of currency resources and side effects of extrovert policies are only the result of exports promotion policies.

Bakhtiari \& HaghI (2001) have worked on the effects of oil incomes on Iran's agricultural sector. Then empirical finally shows that the impact of oil incomes among 1974-1977 resulted in a phenomenon called anti-agricultural. Sachs \& Warner (2001) showed positive relationship between natural resources and general level of prices for 99 countries during 1970 to 1980 as another description of economic poor performance of countries that own natural resources. Evangelina (2001) in his essay works on the impact of oil shocks on employment and economical activities in Greece used VAR model to show that there is a long term relationship between oil price, GDP and employment in Greece. Leaderman \& Maloney (2003) found a positive relationship between natural resources and economic growth by measuring natural resources. Pahlavani (2005) conducted a research on relationship between exports and economic growth by applying cointegration technique. In his research he used Feder applied model in his estimations and showed the effects of structural breaks on macro variables of Iran's economic growth.

\section{Methodology}

Generally, two approaches to model the instability (specially, exports instability) are considered: First approach is to model it as an index. Mir-Shojaei's (1997) approach is an example of this approach for The Organization of the Petroleum Exporting Countries (OPEC) members. Second approach is to model the instability variable in a production function. In this sense, Feder's (1982) traditional approach has been the base for many studies. In his approach, he works on the relationship between exports and economic growth. Few studies usually tried to regulate Feder's model and adjust it with their own findings. Here, in our study we use the second approach and based on Feder's approach we follow the endogenous growth theory and consider human capital in agricultural sector (the number of employed workforce with a university degree) and we will survey the effects of oil exports on agricultural value added. Feder divides the total production in economy in two parts: production for domestic market and production for exports ${ }^{1}$. Therefore, we use the following modified Feder model in logarithm form to examine the oil exports-agricultural value added nexus:

$$
\begin{aligned}
& \operatorname{Ln}\left(y a_{t}\right)=\beta_{0}+\beta_{1} \operatorname{Ln}\left(k a_{t}\right)+\beta_{2} \operatorname{Ln}\left(h a_{t}\right)+\beta_{3} \operatorname{Ln}\left(x o_{t}\right)+\beta_{4} \operatorname{Ln}\left(x a_{t}\right) \\
& +\beta_{5} \operatorname{Ln}\left(\operatorname{mcoa}_{t}\right)+\beta_{6} \operatorname{Ln}\left(\text { mca }_{t}\right)+e_{t}
\end{aligned}
$$

\footnotetext{
${ }^{1}$ Each production is a function of two factors, capital and labor of a given specialty. Moreover the production of non-export sector depends on export capacity too: $Y=X+N, X=G\left(K_{x}, L_{x}\right), N=F\left(K_{n}, L_{n}, X\right)$ Where $L_{x}$ and $L_{n}$ are workforce employed in the relevant section and $K_{X}$ and $K_{n}$ are Capital reserves in the relevant section. If will be applied first and second order derivative, in this case based on the Pareto optimum condition following equality is established in terms of productivity divided by inputs $L$ and $K: G K / F K=G L / F L$ Considering the saving resulting from the high ratio of export production we can assume the following function than the above: $G K / F K=G L / F L=1+d \quad d>0$ Here $\mathrm{d}$ is the amount of savings rates. According to the function $Y=X+N$ and considering a number of assumptions and mathematical operations is extracted following models:

$\dot{Y}=F_{k} \cdot \ddot{K}+F_{l} \cdot \dot{L}+F_{m} \cdot \dot{M}+\left[F_{x}+d /(1+d)\right] \dot{Y}_{x}$
} 
Where $y_{a}$ is real agricultural value added, $k_{a}$ is gross capital formation in agricultural sector, $m c o_{a}$ is real consumer imports in agricultural sector and $m c a_{a}$ is real capital imports in agricultural sector and $h_{a}$ is human capital in agricultural sector. In this equation, oil and agricultural exports are shown by $x о$ and $x a$, respectively. The data are expressed in 1997 constant prices and have been collected from the industrial broadloom in CBI, International Financial Statistics (IFS) and Statistic Center of Iran (SCI). In the next sections we will apply unit roots test with the existence of structural breaks based on the Perron (1989) procedure.

Unit root test with structural break (Perron, 1989): The model employed here is based on Perron (1989), for the existence of a structural break in a series, which appears to be non-stationary ${ }^{1}$ Based on given results of the Perron's model, the unit root null hypothesis is rejected in favor of the alternative hypothesis if the tstatistic for $\rho$ is greater than the critical values tabulated by Perron (1989) ${ }^{1}$. The result is presented in Table 2 .

The table shows that if we enter only one break, variables $L Y a, L H a$ and $L X a$ will lose their non-stationary property; i.e. some of the variables became stationary. Thus, considering the fact that we have stationary and non-stationary variables in the model, using Auto Regressive Distributed Lag (ARDL) co-integration approach is the best solution. Besides, by repeating ARDL in the presence of several structural breaks we conclude that ARDL approach is meaningful at the structural break of 1976 and drought of 1999. So we entered these two variables as Imaginary variables.

Table 2: Unit Root Test Results

\begin{tabular}{|c|c|c|c|c|c|}
\hline Variable & $\begin{array}{l}\text { Constant (C) and Trend } \\
\text { (T) in the equation }\end{array}$ & $\mathrm{T}_{\mathrm{l}}$ & $\lambda$ & t $\rho$ & Result \\
\hline $\operatorname{Ln}(\mathrm{Ya})$ & $\mathrm{C}$ & 1999 & 0.85 & -4.6 & stationary \\
\hline Ln (Xa) & $C \& \mathrm{~T}$ & 1980 & 0.46 & 3.98 & stationary \\
\hline Ln (Ka) & $\mathrm{T}$ & 1976 & 0.36 & 1.26 & non stationary \\
\hline $\operatorname{Ln}(\mathrm{Ha})$ & $\mathrm{T}$ & 1987 & 0.59 & 4.25 & stationary \\
\hline $\operatorname{Ln}(\mathrm{XO})$ & $C \& \mathrm{~T}$ & 1976 & 0.46 & 3.03 & non stationary \\
\hline $\mathrm{Ln}(\mathrm{MCOa})$ & $\mathrm{C}$ & 1999 & 0.8 & 3.67 & stationary \\
\hline Ln (MCAa) & $\mathrm{C}$ & 1980 & 0.85 & 4.31 & stationary \\
\hline
\end{tabular}

Note: Critical values at 1 and 2.5 and 5 and 10 percent levels, for change in the intercept are $-4.27,-3.97,-3.69$ and -3.28 . For change in the trend are $-4.55,-4.20,-3.94$ and -3.66 . For their both are $-4.9,-4.53,-4.24$ and 3.96.

The ARDL Co-integration Approach: Methods such as Engel-Granger deal with small samples in nonvalidation studies because of neglecting the short-term dynamic responses existing between variables. Also since Johansen-Juselius tests are limitations on the condition stationary model variables, are used less than ARDL test. However, one of the major disadvantages of ARDL test is that cannot show more than one equilibrium relationship at estimation of model in unit it.

\section{Results and Discussion}

Long-term test: Exist or non-exist long-term relationship between the dependent variable and other explanatory variables can be examined using the $\mathrm{F}$ test as follows:

$H_{0}: \delta_{1}=\delta_{2}=\delta_{3}=\delta_{4}=\delta_{5}=\delta_{6}=0, H_{1}$ : at least one of the coefficients is zero opposite. Where, $H O$ hypothesis implies that no long-term relationship. $\mathrm{F}$ statistic calculated is compared with the critical point. If the calculated F statistic have been exist between the upper and lower range, the conclusion is not possible and

\footnotetext{
${ }^{1} \rho$ is number of Lags required for independent variable in order to eliminate correlation between error sentences. Based on zero hypothesis $(\rho=1)$ and $\lambda$ values $(\lambda=T B / n)$, Perron statistics critical values was calculated in each of the three cases in own table.
} 
ECM model is used to obtain long-term relationships. We use to estimate ARDL long-run coefficients based on analysis of Pesaran and Smith (1998), the criterion of Schwartz - Bayesian.

Table 3: Estimated long-run coefficients ARDL $(1,0,0,0,0,0,0)$

\begin{tabular}{cccccc}
\hline Regresses & Coefficient & t-Ratio(prob) & Regresses & Coefficient & t-Ratio(prob) \\
\hline $\mathrm{LK}_{\mathrm{a}}$ & 0.54 & $10.11[000]$ & $\mathrm{LMCAa}$ & 0.057 & $2.8[008]$ \\
$\mathrm{LH}_{\mathrm{a}}$ & 0.069 & $5.69[000]$ & Intercept & 6.55 & $5.09[000]$ \\
$\mathrm{LXO}$ & -0.13 & $-4.34[000]$ & DU76 & -0.108 & $-1.78[082]$ \\
$\mathrm{LX}_{\mathrm{a}}$ & 0.16 & $5.91[000]$ & DU99 & -0.19 & $-2.85[007]$ \\
$\mathrm{LMCO}_{\mathrm{a}}$ & -0.2 & $-2.86[006]$ & & & \\
\hline
\end{tabular}

Note: The Schwartz Bayesian Criterion (SBC) is used to select the optimum number of lag in the ARDL model, $\mathrm{F}=7.24[000], \mathrm{D} . \mathrm{W}=2.07, \mathrm{R}^{2}=0.83$

Empirical results in Table 3 show that a one percent increase in agricultural exports leads to 0.16 percent increase in agricultural value added. It is obvious that agricultural exports have an effect on the Iranian economy which, though statistically significant, is less so than expected, and oil exports have an effect of negative on the agricultural value added. It is the oil sector which still generates the bulk of total exports (petrodollars) and acts as the leading sector of the economy. Our empirical finding shows negative relationship and meaningful between structural break of drought (1999) and oil shock at 1974 with agricultural value added.

Short-Term and Error Correction Test: we have selected the value 2 for Maximum log length in ARDL model; also we used F statistics for the variables of LMCOa, LXa, LMCAa, LKa, LHa and LXO as dependent variable. In all these cases, the F statistics value falls below of the lower range and the zero hypotheses cannot reject. Therefore we consider $L Y a$ as dependent variable. Calculated F statistics ( $L Y a$ as dependent) have been equaled to 2.89. According to Pesaran et al (2001) model it is placed between the upper and lower limit at 5 percent, therefore it is used of Error Correction (ECM) model between variables to determine long-term relationships. The results of short-term test show that stability tests are meaningful and their all coefficient are exceed the \%5. Therefore be rejected Functional form problem. The results obtained from the estimate of ECM have been illustrated on Table 4.

Table 4: Estimated Error Correction Model

\begin{tabular}{cccccc}
\hline Regressor & Coefficient & t-Ratio(prob) & Regressor & Coefficient & t-Ratio(prob) \\
\hline $\mathrm{DLK}_{\mathrm{a}}$ & 0.17 & $5.4[000]$ & DLMCA $_{\mathrm{a}}$ & 0.018 & $2.52[016]$ \\
$\mathrm{DLH}_{\mathrm{a}}$ & 0.022 & $4.44[000]$ & $\mathrm{DC}$ & 2.09 & $4.2[000]$ \\
$\mathrm{DLXO}$ & -0.042 & $-3.63[001]$ & DDU76 & -0.03 & $-1.73[091]$ \\
$\mathrm{DLX}_{\mathrm{a}}$ & 0.051 & $4.69[000]$ & DDU99 & -0.06 & $-3.45[001]$ \\
DLMCO $_{\mathrm{a}}$ & -0.06 & $-2.77[008]$ & ECM(-1) & -0.31 & $-6.38[000]$ \\
\hline
\end{tabular}

The error correction term shows a long term relationship between model variables. Banerjee et al. (1998) holds that a highly significant error correction term is further proof of the existence of a stable long-term relationship. Table 4 shows that the expected negative sign of the ECM is highly significant The estimated coefficient of the ECM (-1) is equal to -0.31, suggesting that deviation from the long-term Agricultural value added path is corrected by 0.31 percent over the following year. This means that the adjustment takes place relatively slowly. 
Figure 3: Schematically depicts the actual and forecasted values for the level of $L Y_{a}$ and change in $L Y_{a}$

Dynamic forecasts for the level of

LYA

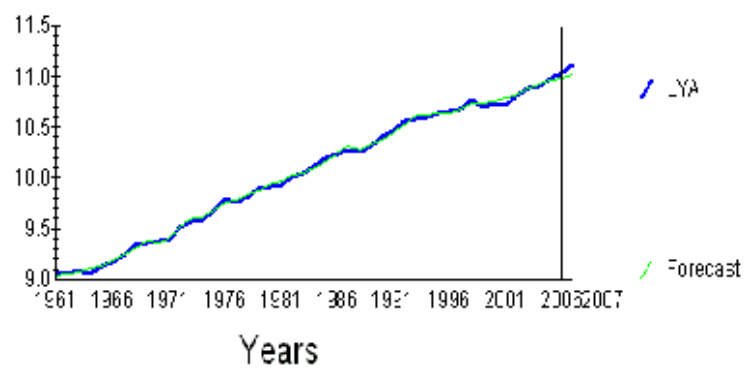

Dynamic forecasts for the change in LYA

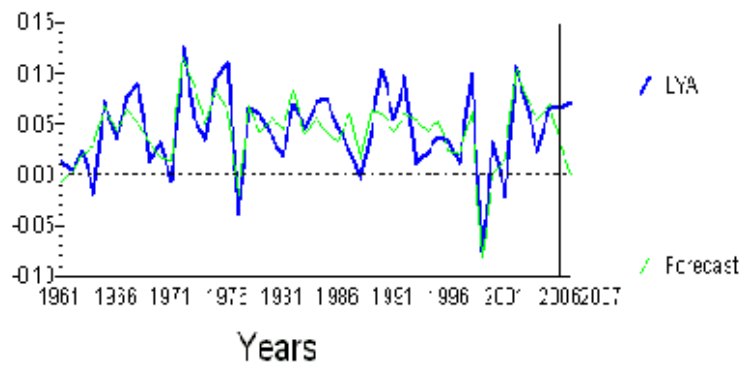

As it is seen in Fig. 2, the estimated model tracks the historical data very well. Serial correlation, functional form, normality, hetroscedasticity, and structural stability are showed by diagnostic tests. As it is seen in Fig. 3 , there is no evidence of autocorrelation and that the model passes the test for normality.

CUSUM and CUSUM of Square test ${ }^{1}$ : When analyzing the stability of the long-run coefficients together with the short-run dynamics, the cumulative sum (CUSUM) and the cumulative sum of squares (CUSUM) point to the in-sample stability of the model (Fig. 3).

Figure 4: Plot of CUSUM and CUSUMQ statistics for coefficients Stability Tests
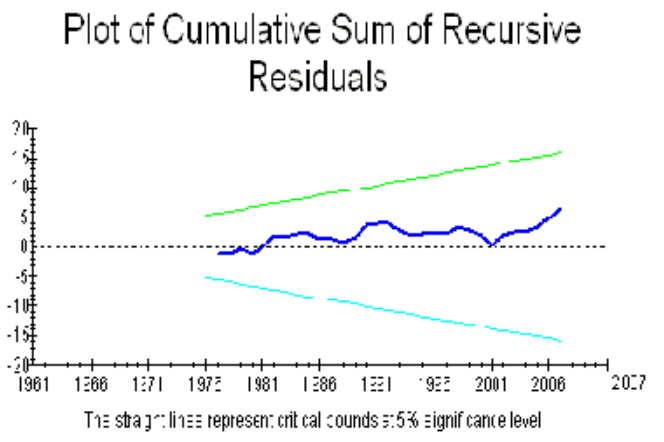

Plot of Cumulative Sum of Squares of Recursive Residuals

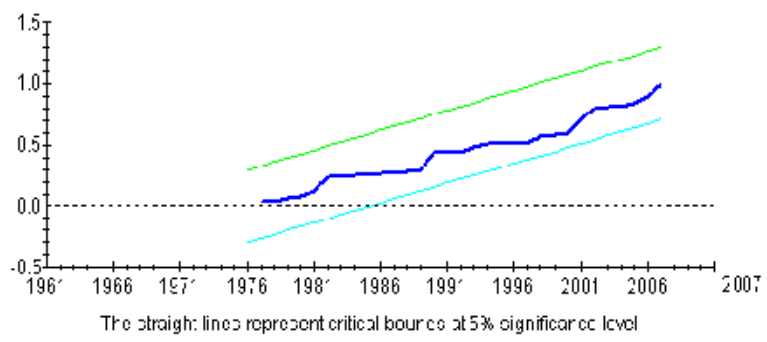

Since the curves of recursive residuals and Square of recursive residuals did not contact Confidence interval in \%95. So zero hypotheses cannot be rejected based on exist of structural stability. Thus is confirmed the structural stability in both cases.

\section{Conclusion and Recommendations}

At first, the results shown that more than half of non-stationary variables with considering structural breaks become stationary. We found that the most significant structural breaks occurring over the last four decades and which were detected endogenously in fact coincide with the drought (1999) and oil price fluctuations (1976). This provides complementary evidence to models employing exogenously imposed structural breaks in the Iranian macroeconomic. Next, we employed an ARDL approach to estimate and validate the long-term short-term determinants of agricultural value added growth in Iran. Our empirical finding indicated that the effect of oil exports on agricultural value added is negative. It means that by Dutch disease phenomena, increasing oil incomes causes decrease activities in traditional and agriculture part that one of its reasons can refer to remove capital from agriculture part to gain parts and partial increasing of agriculture products.

1 SUSUM test is systematic analysis of changes in long-term regression coefficients and CUSUM of Square test is deviation analysis of regression coefficients stability in short-term. 
There is increasing oil incomes accompany with anti agriculture phenomena in Iran. So, the government is suggested to plan and perform some polices and means of proper executive in order to decrease the negative effect of oil price changes on production and improvement of agricultural sector, which will be resulted oil revenues in social economic activities development by proper management. It is very important to pay a great deal of attention to the significance of the issue in view of the dependency of Iran on oil revenues. Furthermore, since there are other factors beside oil effecting production of agricultural sector, these factors should be identified in the future research.

\section{References}

Bakhtiari, S., \& Haghi, Z. (2001). Review of the effects of increase in oil income on agricultural section, Agricultural Economic and Development, 35, 109-38.

Banerjee, A., Dolado, J. J. \& Mestre, R. (1998). Error-Correction Mechanism Tests for Cointegration in a SingleEquation Framework. Journal of Time Series Analysis, 19, 267-284.

Doppelhofer, G., Miller, I. R. \& Sala-i-Martin, X. (2000). Determinants of Long-Term Growth: a Bayesian Average of Classical Estimates (BACE) Approach, NBER Working Paper, No. 7750.

Esfahani, H. S. (1991). Exports, Imports and Economic Growth in Semi-Industrialized Countries. Journal of Development Economics 35, 93-116.

Evangelia, P. (2001). Oil price shocks, stock market, economic activity and employment in Greece. Energy Economics, 23(5), 511-532.

Feder, G. (1982). On Exports and Economic Growth. Journal of Development Economics, 12, 59-73.

Fosu, A. (1996). Primary Exports and Economic Growth in Developing Countries. World Economy, 20, 465475.

Gorden, W. M. \& Neary, J. P. (1982). Booming sector and deindustrialization in a small open economy. Economic Journal, 92, 825-848.

Leaderman, D. \& Maloney, W. F. (2003). Trade Structure and Growth, World Bank Policy Research Working Paper, No. 3025.

Mellor, J. W. (1995). Agriculture on the Road to Industrialization, Baltimore MD: Johns Hopkins University Press.

Mir Shojai, F. (1997). Exports Instability and Economic Growth in OPEC Member Countries. Trade Research Magazine.

Neary J. P. \& Van Wijnbergen, S. (1986). Natural resources and the macro economy: A theoretical framework. In Natural Resources and the Macro economy, ed. Neary and Van Wijnbergen, 13-45. Oxford: Basil Blackwell.

Pahlavani, M. (2005). Sources of Economic Growth in Iran: A Cointegration analysis in the presence of structural breaks. Applied Econometrics and international Development, 5(4), 83-94.

Pesaran, M. H. \& Smith, R. (1998). Structural Analysis of Cointegrating VARS. Journal of Economic Surveys, 12(5), 471-505.

Pesaran, H. Shin, Y. \& Smith, R. (2001). Bound testing approaches to the analysis of level relationships. Journal of Applied Econometrics, 16, 289-326.

Perron, P. (1989). The Great Crash, the Oil Price Shock, and the Unit Root Hypothesis. Econometrica, 57(6), 1361-1401.

Sachs, J. \& Warner, A. (2001). Natural Resource Abundance and Economic Development. The Curse of Natural Resources. European Economic Review, 45, 827-838.

Sala-i-Martin, X. (1997). Just Run Two Million Regressions. American Economic Review, Papers and Proceedings, 87, 178-183.

Salter, W. E. G., (1959). Internal and External Balance: The Role of Price and Expenditure Effects. Economic Record, 35(171), 226-238.

Sheehey, E. J. (1990). Export and Growth: A Flawed Framework. Journal of Development Studies, 2(1), 111116. 